\title{
INNATE LYMPHOID CELLS: ROLES IN TUMOUR GENESIS AND PROGRESSION
}

Ivan Jovanovic, Nevena Gajovic, Gordana Radosavljevic, Jelena Pantic, Nada Pejnovic, Nebojsa Arsenijevic, Miodrag L. Lukic Center for Molecular Medicine and Stem Cell Research, Faculty of Medical Sciences, University of Kragujevac, Serbia

\section{UROĐENE LIMFOIDNE ĆELIJE- ULOGA U GENEZI I RASTU TUMORA}

Ivan Jovanović, Nevena Gajović, Gordana Radosavljević, Jelena Pantić, Nada Pejnović, Nebojša Arsenijević, Miodrag L. Lukić
Centar za molekulsku medicinu i istraživanje matičnih ćelija, Fakultet medicinskih nauka, Univerzitet u Kragujevcu, Srbija

\section{ABSTRACT}

Innate lymphoid cells (ILCs) represent the most recently identified members of the innate immune system. These cells play important roles in inflammation, tissue remodelling and metabolic disease. ILCs can be subdivided into three major groups according to their cytokine production. The role of ILCs in tumourigenesis and tumour progression is not completely clarified. In this review, we discuss whether and how ILCs are involved in tumour genesis, growth and metastasis.

Keywords: Innate lymphoid cells, tumour, progression, antitumor immunity

\section{INNATE LYMPHOID CELLS}

The innate immune response is important in combating various microbes during the early phases of infection. Innate lymphoid cells (ILCs) represent the most recently identified constituents of the innate immune system by playing a role in inflammation, tissue remodelling and metabolic disease (1). ILCs lack the known immune cell lineage markers. Unlike T and B lymphocytes, ILCs do not have antigen receptors and memory functions (2). ILCs are localized in intestinal and lung mucosae as well as the skin and are capable of rapidly switching on responses to pathogens, even upon first exposure (1). These cells can be subdivided into three major groups according to their cytokine production (Fig 1; 3-4). The ILC2 group represents the innate equivalent of Th2 cells. This group only includes ILC2 cells (e.g., nuocytes, natural helper cells, innate helper cells, and multipotent progenitor cells) that secrete IL-5 and IL-13 in response to IL-25, IL-33 and thymic stromal lymphopoietin (TSLP), and they mediate innate responses during helminth infections and allergies (1-2). The ILC1 group is composed of ILC1 cells and natural killer (NK) cells. They represent the innate equivalent of adaptive Th1 and cytotoxic T cells, re-

\section{SAŽETAK}

Urođene limfoidne ćelije (engl. Innate lymphoid cells-ILCs) predstavljaju populaciju nedavno opisanih ćelija urođene imunosti. Ove ćelije igraju značajnu ulogu u zapaljenju, obnavljanju tkiva i metaboličkim poremećajima. U zavisnosti od produkcije citokina, ILCs se mogu podeliti u tri glavne subpopulacije. Uloga ILCs u tumorogenezi i progresiji bolesti nije u potpunosti razjašnjena. U ovom preglednom članku, mi razmatramo da li i kako ILCs utiču na genezu, rast $i$ metastaziranje tumora.

Ključne reči: Urođene limfoidne ćelije, tumor, progresija, antitumorska imunost

\section{○า}

spectively. While NK cells play well-known roles in antiviral and antitumour immunity, several additional ILC1s have recently been identified that produce IFN- $\gamma$. The ILC3 group includes ILC3 cells and lymphoid tissue inducer (LTi) cells $(1,5)$. These cells mainly secrete IL-17 and IL-22 in response to IL-23 and IL-1b, and they represent the innate equivalents of Th17 and Th22 cells, respectively. The development and differentiation as well as effector functions of the ILCs are dependent upon the transcription factor, $\operatorname{GATA3}(1,6)$.

The role of ILCs in inflammatory immune responses, tissue remodelling and metabolic disease are well documented (Fig 1;1,2,7). Recent studies described the involvement of ILCs in tumour growth and progression (8-11). In this paper, we summarize the role of ILCs in tumour genesis and anti-tumour immunity modulation.

\section{THE HISTORY OF INNATE LYMPHOID CELLS}

Natural killer (NK) cells were the first discovered ILCs. Five years ago, a new type of innate lymphoid cells was described in fat-associated lymphoid clusters (FALCs). These cells did 


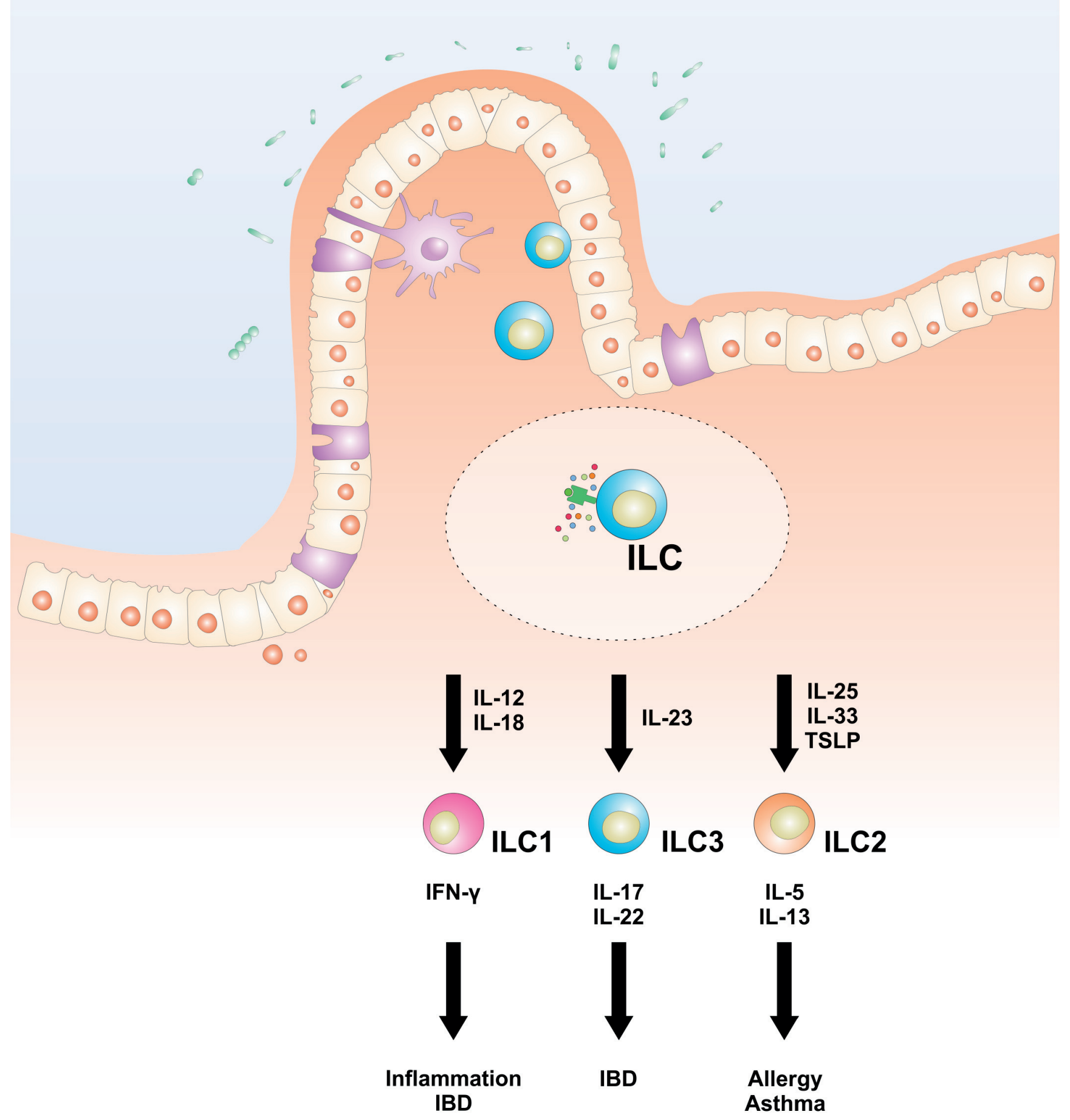

Figure 1. Innate lymphoid cell classifications. The classification of innate lymphoid cells (ILCs) is based on functional criteria. ILC1s are defined by their capability to produce interferon- $\gamma$ (IFN $\gamma$ ). ILC2s produce type 2 cytokines, interleukin-5 (IL-5) and IL-13. ILC3s are capable of producing the type 17 cytokines IL-17 and IL-22. Different subsets of ILCs cells play various roles in disease immuno-pathogenesis and subsequent tissue destruction and systemic manifestations. 
not express lineage (Lin) markers but expressed c-Kit, Sca-1 (also known as Ly6a) and ST2 (12). The authors named them natural helper cells (NHCs). NHCs were shown to proliferate in response to IL-2 and to produce large amounts of type 2 cytokines such as IL-5 and IL-13 in response to IL-33 stimulation and also to require IL-7 for survival (12). NHCs regulate B-cell antibody production and self-renewal of B1 cells. The authors concluded that the described FALC Lin ${ }^{-} \mathrm{c}-\mathrm{Kit}^{+} \mathrm{Sca}-1^{+}$ cells (NHCs) acted like Th2-type innate lymphocytes (12). Novel innate lymphocytes, termed multipotent progenitor (MMP) cells, were discovered at a same time (13). IL-25 (also known as IL-17E) promotes the accumulation of $\mathrm{Lin}^{-} \mathrm{Sca}-1^{+}$ c-Kit ${ }^{\text {int }}$ MMP cells in gut-associated lymphoid tissue with subsequent type 2 cytokine production (13). In the same year, this second group of investigators identified a population of lineage negative IL-13 producing cells (14). They named them "nuocytes" due to their IL-13 production (nu is the $13^{\text {th }}$ letter of the Greek alphabet). These cells did not express Lin markers but expressed ICOS, ST2, IL17BR and IL17R $\alpha$ (14). Nuocytes play a critical role in inducing helminth expulsion. These cells expand rapidly in response to IL-25 and IL-33 (type 2 inducing cytokines) and in response to infection of the helminth, Nippostronglylus brasiliensis. Nuocytes secrete high IL-5 and IL-13 levels and present highly specialized type 2 regulatory cells (14). Three independent research groups defined innate lymphoid cells, termed multipotent progenitor (MMP) cells, natural helper cells and nuocytes in the gutassociated mucosa tissues, in the same year (12-14). Whether these cell types exist in organs other than the digestive system was unknown. At that time, it was already known that intranasal administration of the type 2-inducing cytokines, IL-25 and IL-33, induced eosinophilia in the lungs of mice lacking $\mathrm{T}$ and $\mathrm{B}$ lymphocytes, indicating that another cell population was capable of facilitating localized inflammation (15). Chang et al. reported the presence of $\mathrm{Lin}^{-} \mathrm{C}-\mathrm{Kit}^{+} \mathrm{Sca}-1^{+} \mathrm{ST} 2^{+}$cells in the lungs and their contribution to the development of airway hyper-reactivity via IL-33 signalling (16). In this study, H3N1 influenza infection induced airway hyper-reactivity, which is a cardinal feature of asthma, through the accumulation and activation of innate lymphoid cells. These cells produced large amounts of IL-5 and IL-13, which facilitate the genesis and progression of airway hyper-reactivity and intensive mucus secretion in the airways (16). Another research group described innate lymphocytes, termed lung natural helper ( $\mathrm{LNH}$ ) cells, as a T cell-independent source of type 2 cytokines (17). The cells were defined as $\mathrm{Lin}^{-} \mathrm{Sca}-1^{+} \mathrm{C}-\mathrm{Kit}^{+/ l o}$
$\mathrm{CD}^{2} 5^{+} \mathrm{CD} 127^{+}$cells. After stimulation with IL-33 and IL-2, IL-7 or TSLP, the LNH cells produced IL-5 and IL-13 (17). Innate lymphoid cells in the lungs were capable of rapidly responding to lung epithelium-derived cytokines. Further, they can be divided into two distinct populations: NK cells and cytokine producing ILCs (17). Barthemes et al. described the IL-33 responsive ILCs that reside in the lungs (18). These lung lymphoid cells were Lin ${ }^{-}$c-Kit Sca- $1^{+}$CD $44^{+}$CD $25^{+}$Thy $1.2^{+}$ IL-7R $\alpha^{+} \mathrm{ICOS}^{+}$and produced large quantities of IL-5 and IL13 after exposure to the fungal allergen, Alternaria alternata (18). The authors suggested that allergic airway inflammation can develop independently of adaptive immunity, and lung Lin $^{-}$CD $44^{\text {hi }}$ CD25 $5^{+}$cells were sufficient to induce airway inflammation (18). An important pathogenic role of novel ILCs was confirmed by the identification and expansion of these cells in various allergy and parasitic inflammation models (18-21). ILCs are important producers of IL-9 during airway inflammation $(14,22)$. It has now been shown that Lin- ST2+ cells are the main source of IL-9. IL-33 was shown to induce the accumulation of ILCs that produce IL-9 (22).

Additionally, ILCs play an important role in tissue remodelling. It was shown that, during influenza virus-induced airway inflammation, ILCs produce the epidermal growth factor-related cytokine, amphiregulin, which further regulates epithelial cell repair (23).

Common traits for all types of the described innate lymphoid cells are that they are systemically dispersed and expanded in response to IL-33 and/or IL-25, in vivo, express similar surface markers and produce large quantities of IL-5 and IL-13 after activation (24). This finding indicates that these populations might be closely related. All of these cells have been classified into the ILC2 group.

ILC1s are defined by the production of IFNY and the inability to produce type $2 / 17$ cytokines $(1,2)$. The prototypical member of this group is the NK cell. First discovered in 1975, natural killer (NK) cells were the first discovered ILCs (25). Unlike T and B lymphocytes, these innate lymphocytes do not express antigen receptors but rapidly exhibit cytotoxic activities against virus-infected and tumour cells and produce various cytokines $(1,2)$. The origins and roles of NK cells in anti-viral and anti-tumour immunity are well established and they will not be discussed here. NK cells not only display cytotoxic activity, but they are also able to produce large quantities of IFN- $\gamma$ following activation. Recent studies have identified another ILC1 subset that produces IFN- $\gamma(2,26,27)$. These cells do not secrete type $2 / 17$ cyto-

\begin{tabular}{|l|l|}
\hline \multirow{4}{*}{ Table 1. Innate lymphoid cells in tumour genesis and progression } \\
\hline \multirow{2}{*}{ ILC2s } & Eosinophil accumulation and antitumour immunity via IL-5 (11) \\
\cline { 2 - 3 } & MDSCs and Treg accumulation and immunosuppression via IL-13 (8) \\
\cline { 2 - 3 } ILC3s (IL-17 $)$ & Carcinogenesis via IL-13 (51,52) \\
\hline ILC3s (IL-22 & Facilitate tumourigenesis, angiogenesis and metastasis (55) \\
ILC1s (NK) & Stimulate pro- and anti-tumour mechanisms (59) \\
\hline
\end{tabular}


kines and represented a population that is distinct from NK cells $(2,26,27)$. The development of NK cells is dependent upon T-bet expression, and they occur independently of GATA3, while the development of ILC1s is dependent upon both GATA3 and T-bet expression (4). ILC1 cells express high T-bet levels and low RORyt levels (27). These CD117cells express IL-7Ra and CXCR3 and secrete IFN- $\gamma$, TNF- $\alpha$, CCL3, and CCL4 in response to activation via IL-12, IL-15 and IL-18, and they play role in immune defence to Salmonella spp. infections and in Crohn's disease immunopathogenesis (1, 2, 27-29).

A recent study described various ILC3 subsets in intestinal tissues $(1,5,30-33)$. The ILC3 group includes ILC3 cells and lymphoid tissue inducer (LTi) cells $(1,5)$. One of the ILC3 subsets that was described in the tonsils, Peyer's patches, appendix and colon lamina propria consists of cells that expresses the NK cell receptor, NKp44/NKp46, and CCR6 and secretes IL-22 but not IL-17 upon IL-23 stimulation (30-32). Another ILC3 subset was discovered in disease affected tissue of Crohn's disease patients and secretes IL-17 and IFN- $\gamma$ (33). Foetal mesenteric lymph nodes harbour ILC3s that secrete IL-17 and IL-22 (34). LTi cells, which are mediators of innate immunity, can be activated via an IL-23-dependent manner and represent the dominant source of IL-22 during early infections (36). ILC3s mainly secrete IL-17 and IL-22 in response to IL-23 and IL- $1 \mathrm{~b}$, and represent the innate equivalents of Th17 and Th22 cells (30-35). IL-22 triggers antimicrobial peptide release and promotes epithelial cell proliferation, thereby preserving epithelial barrier integrity $(1,2,5$, 30-35). IL-17 elicits neutrophil recruitment. A recent study found that ILC3s, in particular LTi cells, express MHC class II molecules and present antigen to $\mathrm{CD} 4^{+} \mathrm{T}$ cells, indicating an impact of ILC3s on adaptive immune responses (37). However, interactions with $\mathrm{T}$ lymphocytes did not lead to activation and subsequent proliferation, but these interactions led to tolerance of presented antigens (37). Cella et al. revealed that NKp44+ ILC3s produce BAFF (B-cell activating factor) and promote $\mathrm{B}$-cell activation and survival within mucosal tissues $(30,32)$.

\section{THE ROLE IF ILCS IN TUMOUR GROWTH AND PROGRESSION}

The role of ILC2s in tumour growth and progression was established in a few tumour models (Table 1). A recent report showed that IL-33 mediated an increased level of IL-5-producing ILCs that further regulated the antitumour activity of eosinophils in a lung tumour metastasis model (11). In this study, the authors used a lung metastatic melanoma cell line and observed an accumulation of innate IL-5-producing cells that regulated eosinophil influx into the lung. The innate IL-5-producing cells were similar to the natural helper cells, nuocytes and innate type 2 helper cells, and the majority of which were lineage negative and expressed Sca-1, Thy1.2, CD25, CD27, CD44, CD69, IL-7Ra and ST2, which is a subunit of IL-33R (11). Further, they showed responsiveness of
ILCs to IL-25 and IL-33, indicating that these IL-5-producing cells belong to the ILC2 class of cells. After induction of a lung metastatic melanoma model, the authors found that exogenous IL-25 and IL-33 mediated infiltration of eosinophils into the lung via IL-5. Specifically, IL-25 and IL-33 induced accumulation of the innate IL-5-producing ILC2s, which in turn recruited eosinophils into the lung. Antitumour immunity is mediated by the innate and adaptive immune system $(38,39,40,41,42)$. Polarization of antitumour immune response influences tumour growth in a dual manner. Polarization towards the type 1 response preferentially activates cellular immunity (by producing IFN- $\gamma$ and IL-2), while the type 2 immune response suppresses cellular immunity by eliciting humoral immunity (via IL-4, IL-5 IL-10, and IL-13 production) (40, 43- 45). The type 1-mediated antitumour immune response is followed by potent stimulation of T-cell cytotoxic activity $(39,40,41,46)$. On the contrary, type 2 polarization results in the production of growth factors and cytokines that support tumour growth and metastasis (43). Although type 2 cytokines downregulate antitumour immunity, they can promote the recruitment of tumouricidal eosinophils and macrophages into the tumour microenvironment $(40,41,43,44)$. In the present study, Ikutani et al. concluded that ILC2s facilitate the accumulation of tumouricidal eosinophils in the lung and may play an important role in tumour surveillance (11). However, eosinophils possess both pro- and anti-tumour activities that are dependent on the tumour microenvironment and type $(47,48)$. The role of ILC2s in tumour growth needs to be further clarified.

Our initial work on this subject was based on a highly malignant and poorly immunogenic murine tumour model, which shares many characteristics with naturally occurring human breast cancer (8). In this study, we aimed to investigate the effects of exogenously administered IL-33 on tumour appearance and progression and on the mechanisms of anti-tumour immunity. We found that IL-33 enhanced mammary carcinoma growth and lung and liver metastasis by facilitating the expansion of immune suppressor cells within the tumours and by diminishing innate anti-tumour immunity (8). IL-33 administration expanded IL-13 producing innate lymphoid cells within the mammary tumour. These tumour infiltrating lymphoid cells were CD $45^{+} \mathrm{Lin}^{-} \mathrm{Sca}-1^{+} \mathrm{CD} 44^{+} \mathrm{CD} 25^{+} \mathrm{ST} 2^{+}$and produced IL-5 and IL-13 in response to IL-33 and were IL-4, IL-10 and IFN- $\gamma$ negative, indicating that they had an ILC2 phenotype (8). IL-33 increased the frequencies of IL-5 and IL-13 expressing ILCs and circulating levels of IL-13 in tumourbearing hosts (8). ILC2s have been shown to facilitate Type 2 immune responses while preventing Type 1-mediated immunity $(11,12,14,17,49)$; however, their roles in cancer progression are not well defined. We assumed that ILCs directly affect myeloid-derived suppressor cell (MDSC) activity via IL-13. MDSCs are usually recruited to tumour sites from peripheral lymphoid organs where they promote the CD4 ${ }^{+} \mathrm{Foxp}^{+}{ }^{+}$Treg generation (IJC 33) and exert immunosuppressive effects via TGF-b production. It is well known that MDSCs require the presence of IL-13 for 
their activity, e.g., arginase and nitric oxide synthase II expression (50). In line with our conclusion, we also demonstrated IL-33 mediated an increase of CD11b+ CD11c ${ }^{-}$Gr$1^{+}$MDSCs within mammary tumours (8). These MDSCs expressed IL- $13 \alpha 1$ receptors and produced TGF- $\beta$ (8). Our findings revealed a novel role for IL-33 in the mechanisms of breast cancer immune escape via the ILC2s/IL-13/MDSCs/ TGF- $\beta$ /Tregs axis (8).

In another study, intra-biliary injection of IL-33 into mice with active Akt and Hippo pathways facilitated cholangiocarcinoma development, indicating a role of IL-33 in cholangiocyte proliferation, biliary repair, and carcinogenesis via the ILC2s/IL-13 axis $(51,52)$.

The role of ILC3s in tumour growth and progression was also described (Table 1). ROR $\gamma \mathrm{t}^{+}$ILC3s are a main source of IL-17 and IL-22 (second to Th17 cells in terms of production) (53). Studies have shown that ROR $\gamma \mathrm{t}^{+}$ILC3s accumulate in the intestine of inflammatory bowel disease (IBD) patients and are a crucial IBD pathogenic factor (33, 53). In chronic gastrointestinal infection or acute stimulation with chemical carcinogens, IL-17-producing IL-23R ${ }^{+}$ ILC3s induce gut tumourigenesis through the IL-23/IL17 signalling pathway, which promotes angiogenesis and tumour metastasis $(54,55)$. Some experiments suggested that IL-22 producing ILC3s promote inflammation in active intestinal diseases $(33,56-58)$. IL-22 may promote pro- and anti-tumour mechanisms depending on the tissue microenvironment and tumour characteristics. Thus, in pathogen-induced cancers, IL-22 inhibits tumour growth by promoting the elimination of viral or bacterial infections and termination of inflammation. In contrast, IL-22 may facilitates angiogenesis and promotes cancer growth (59). Studies have shown that IL-22 together with other factors contributes to tumour formation $(60,61)$.

It has been known for decades that NK cells provide protection against viruses and tumour cells. The role of NK cells in immune surveillance is well established (62-66). NK cell activity is variable during tumour progression and is related to clinical stages and disease outcome (65-70). During the cytotoxic killing of tumour cells, NK cells and CD8 ${ }^{+} \mathrm{T}$ cells rapidly release granules that contain perforin and granzymes into immunological synapses, thereby inducing target cell death (71). NK cell activity is the major mechanism of innate immunity against tumours (42). NK cells lyse tumour cells without prior sensitization and represent the first line of defence against tumours and cancer metastasis (42).

Recent studies have achieved significant progress towards defining subpopulations of ILCs. ILC1s, ILC2s and ILC3s are now emerging as important cell populations that regulate tissue homeostasis and inflammation. Several studies have described the effects of ILCs on the genesis, growth and progression of tumours and the modulation of antitumour immune responses. However, much of the current knowledge regarding ILCs is based on experimental models and still requires confirmation in humans. Extensive clinical investigations are still needed to clarify the intrinsic roles of ILCs in response to tumours.

\section{ACKNOWLEDGEMENTS}

This work was supported by grants from the Serbian Ministry of Science and Technological Development (175069, 175071 and 175103), Serbia and from the Kragujevac medical sciences faculty (project MP 01/12), Serbia. The authors thank Milan Milojevic for the excellent technical assistance.

\section{CONFLICT OF INTEREST}

The authors declare no financial or commercial conflicts of interest.

\section{REFERENCES}

1. Tian Z, van Velkinburgh JC, Wu Y, Ni B. Innate lymphoid cells involve in tumourigenesis. Int J Cancer. 2015; doi: 10.1002/ijc.29443.

2. Fuchs A, Colonna M. Innate lymphoid cells in homeostasis, infection, chronic inflammation and tumours of the gastrointestinal tract. Curr Opin Gastroenterol 2013; 29: 581-7.

3. Constantinides MG, McDonald BD, Verhoef PA, Bendelac A. A committed precursor to innate lymphoid cells. Nature 2014; 508: 397-401.

4. Spits $H$, Artis D, Colonna $M$ et al. Innate lymphoid cells- a proposal for uniform nomenclature. Nat Rev Immunol 2013; 13: 145-9.

5. Montaldo E, Vacca P, Moretta L, Mingari MC. Development of human natural killer cells and other innate lymphoid cells. Semin Immunol 2014; 26: 107-13.

6. Yagi R, Zhong C, Northrup DL et al. The transcription factor GATA3 is critical for the development of all IL7Ralpha-expressing innate lymphoid cells. Immunity 2014; 40: 378-88.

7. Spits H, Di Santo JP. The expanding family of innate lymphoid cells: regulators and effectors of immunity and tissue remodelling. Nat Immunol 2011; 12: 21-7.

8. Jovanovic I, Pejnovic N, Radosavljevic G et al. Interleukin-33/ST2 axis promotes breast cancer growth and metastases by facilitating intratumoural accumulation of immunosuppressive and innate lymphoid cells. Int J Cancer 2013; 134: 1669-82.

9. Liu J, Duan Y, Cheng X et al. IL-17 is associated with poor prognosis and promotes angiogenesis via stimulating VEGF production of cancer cells in colorectal carcinoma. Biochem Biophys Res Commun 2011; 407: 348-54.

10. Kirchberger S, Royston DJ, Boulard O et al. Innate lymphoid cells sustain colon cancer through production of interleukin-22 in a mouse model. J Exp Med 2013; 210: 917-31.

11. Ikutani M, Yanagibashi T, Ogasawara $M$ et al. Identification of innate IL-5-producing cells and their role in lung eosinophil regulation and antitumour immunity. J Immunol 2012; 188: 703-13. 
12. Moro K, Yamada T, Tanabe M et al. Innate production of $\mathrm{T}(\mathrm{H}) 2$ cytokines by adipose tissue-associated c-Kit(+)Sca-1(+) lymphoid cells. Nature 2010; 463 (7280): 540-4.

13. Saenz SA, Siracusa MC, Perrigoue JG et al. IL25 elicits a multipotent progenitor cell population that promotes $\mathrm{T}(\mathrm{H}) 2$ cytokine responses. Nature. 2010; 464: 1362-6.

14. Neill DR, Wong SH, Bellosi A et al. Nuocytes represent a new innate effector leukocyte that mediates type- 2 immunity. Nature. 2010; 464(7293): 1367-70.

15. Hurst SD, Muchamuel T, Gorman DM et al. New IL-17 family members promote Th1 or Th2 responses in the lung: in vivo function of the novel cytokine IL-25. J Immunol. 2002; 169: 443-53.

16. Chang YJ, Kim HY, Albacker LA et al. Innate lymphoid cells mediate influenza-induced airway hyper-reactivity independently of adaptive immunity. Nat Immunol. 2011; 12: 631-8.

17. Halim TY, Krauss RH, Sun AC, Takei F. Lung natural helper cells are a critical source of Th2 cell-type cytokines in protease allergen-induced airway inflammation. Immunity 2012; 36: 451-63.

18. Bartemes KR, Iijima K, Kobayashi T, Kephart GM, McKenzie AN, Kita H. IL-33-responsive lineageCD25+ CD44(hi) lymphoid cells mediate innate type 2 immunity and allergic inflammation in the lungs. J Immunol 2012; 188: 1503-13.

19. Barlow JL, Bellosi A, Hardman CS et al. Innate IL13-producing nuocytes arise during allergic lung inflammation and contribute to airways hyperreactivity. J Allergy Clin Immunol 2012; 129: 191-8.

20. Kim HY, Chang YJ, Subramanian S et al. Innate lymphoid cells responding to IL-33 mediate airway hyperreactivity independently of adaptive immunity. J Allergy Clin Immunol 2012; 129: 216-27.

21. Yasuda K, Muto T, Kawagoe T et al. Contribution of IL33-activated type II innate lymphoid cells to pulmonary eosinophilia in intestinal nematode-infected mice. Proc Natl Acad Sci U S A. 2012; 109: 3451-6.

22. Wilhelm C, Hirota K, Stieglitz B et al. An IL-9 fate reporter demonstrates the induction of an innate IL-9 response in lung inflammation. Nat Immunol 2011; 12: 1071-7.

23. Monticelli LA, Sonnenberg GF, Abt MC et al. Innate lymphoid cells promote lung-tissue homeostasis after infection with influenza virus. Nat Immunol 2011; 12: 1045-54.

24. Mirchandani AS, Salmond RJ, Liew FY. Interleukin-33 and the function of innate lymphoid cells. Trends Immunol 2012; 33: 389-96.

25. Kiessling, R. Klein, E., Pross, H. \& Wigzell, H. "Natural" killer cells in the mouse. II. Cytotoxic cells with specificity for mouse Moloney leukaemia cells. Characteristics of the killer cell. Eur. J. Immunol. 1975; 5: 117-121.

26. Vonarbourg C, Mortha A, Bui VL et al. Regulated expression of nuclear receptor RORyt confers distinct functional fates to NK cell receptor-expressing ROR $\gamma \mathrm{t}+$ innate lymphocytes. Immunity 2010; 33: 736-751
27. Bernink JH, Peters CP, Munneke M et al. Human type 1 innate lymphoid cells accumulate in inflamed mucosal tissues. Nat Immunol. 2013; 14: 221-9.

28. Klose CS, Flach M, Möhle L et al. Differentiation of type 1 ILCs from a common progenitor to all helper-like innate lymphoid cell lineages. Cell 2014; 157: 340-56.

29. Maloy KJ, Uhlig HH. ILC1 populations join the border patrol. Immunity 2013; 38: 630-2.

30. Cella M, Fuchs A, Vermi W et al. A human natural killer cell subset provides an innate source of IL-22 for mucosal immunity. Nature 2009; 457: 722-725.

31. Takayama T, Kamada N, Chinen $\mathrm{H}$ et al. Imbalance of NKp44(p)NKp46(-) and NKp44(-) NKp46(p) natural killer cells in the intestinal mucosa of patients with Crohn's disease. Gastroenterology 2010; 139: 882-892

32. Cella M, Otero K, Colonna M. Expansion of human NK-22 cells with IL-7, IL-2, and IL-1beta reveals intrinsic functional plasticity. Proc Natl Acad Sci USA 2010; 107: 10961-10966.

33. Geremia A, Arancibia-Cárcamo CV, Fleming MP et al. IL-23-responsive innate lymphoid cells are increased in inflammatory bowel disease. J Exp Med 2011; 208:1127-1133.

34. Cupedo T, Crellin NK, Papazian N et al. Human foetal lymphoid tissue-inducer cells are interleukin 17-producing precursors to RORC+ CD127+ natural killerlike cells. Nat Immunol 2009; 10: 66-74.

35. Ivanov II, Diehl GE, Littman DR. Lymphoid tissue inducer cells in intestinal immunity. Curr Top Microbiol Immunol 2006; 308: 59-82.

36. Takatori H, Kanno Y, Watford WT et al. Lymphoid tissue inducer-like cells are an innate source of IL-17 and IL-22. J Exp Med 2009; 206: 35-41.

37. Hepworth MR, Monticelli LA, Fung TC et al. Innate lymphoid cells regulate $\mathrm{T}$-cell responses to intestinal commensal bacteria. Nature 2013; 498: 113-117.

38. Plunkett TA, Correa I, Miles DW and Taylor-Papadimitriou J. Breast cancer and the immune system: opportunities and pitfalls. J. Mammary Gland Biol. Neoplasia 2001. 6: 467-475.

39. Ito N, Nakamura H, Tanaka Y and Ohgi S. Lung carcinoma: analysis of T-helper type 1 and 2 cells and Tcytotoxic type 1 and 2 cells by intracellular cytokine detection with flow cytometry. Cancer 1999. 85: 23592367.

40. Nishimura T, Nakui M, Sato M et al. The critical role of Th1-dominant immunity in tumour immunology. Cancer Chemother. Pharmacol. 2000. 46: 52-61.

41. Dobrzanski MJ, Reome JB, Hylindand JC and RewersFelkins KA. CD8 mediated type 1 antitumour responses selectively modulate endogenous differentiated and nondifferentiated $\mathrm{t}$ cell localization, activation, and function in progressive breast cancer. J. Immunol. 2006. 177: 8191-8201.

42. Vujanovic NL, Basse P, Herberman RB and Whiteside TL. Antitumour functions of natural killer cells and control of metastasis. Methods 1996. 9: 394-408. 
43. Hung K, Hayashi R, Lafond-Walker A, Lowenstein C, Pardoll D and Levitsky $\mathrm{H}$. The central role of CD41 T cells in the antitumour immune response. J. Exp. Med. 1998. 188: 2357-2368.

44. Ellyard JI, Simson L, Parish CR. Th2-mediated antitumour immunity: friend or foe? Tissue Antigens 2007. 70: $1-11$.

45. Stout RD and Bottomly K. Antigen- specific activation of effector macrophages by IFN-g producing (TH1) $\mathrm{T}$ cell clones. Failure of IL-4-producing (TH2) T cell clones to activate effector function of macrophages. J. Immunol. 1989. 142: 760-765.

46. Hu HM, Urba WJ and Fox BA. Gene-modified tumour vaccine with therapeutic potential shifts tumour-specific $\mathrm{T}$ cell response from a type 2 to a type 1 cytokine profile. J. Immunol. 1998; 161: 3033-3041.

47. Akbari O, DeKruyff RH, Umetsu DT. Pulmonary dendritic cells producing IL-10 mediate tolerance induced by respiratory exposure to antigen. Nat Immunol 2001; 2: 725-31.

48. Guedez L, Jensen-Taubman S, Bourboulia D et al. TIMP-2 targets tumour-associated myeloid suppressor cells with effects in cancer immune dysfunction and angiogenesis. J Immunother 2012; 35: 502-12.

49. Koyasu S, Moro K. Type 2 innate immune responses and the natural helper cell. Immunology 2011; 132: 475-81.

50. Gabitass RF, Annels NE, Stocken DD et al. Elevated myeloid-derived suppressor cells in pancreatic, oesophageal and gastric cancer are an independent prognostic factor and are associated with significant elevation of the Th2 cytokine interleukin-13. Cancer Immunol Immunother 2011; 60: 1419-30.

51. Li J, Razumilava N, Gores GJ et al. Biliary repair and carcinogenesis are mediated by IL-33- dependent cholangiocyte proliferation. J Clin Invest 2014; 124: 3241-51.

52. Patman G. Biliary tract. IL-33, innate lymphoid cells and IL-13 are required for cholangiocyte proliferation. Nat Rev Gastroenterol Hepatol 2014; 11: 456.

53. Pearson C, Uhlig HH, Powrie F. Lymphoid microenvironments and innate lymphoid cells in the gut. Trends Immunol 2012; 33: 289-96.

54. Chan IH, Jain R, Tessmer MS et al. Interleukin- 23 is sufficient to induce rapid de novo gut tumourigenesis, independent of carcinogens, through activation of innate lymphoid cells. Mucosal Immunol 2014; 7: 842-56.

55. Murugaiyan G, Saha B. Protumour vs antitumour functions of IL-17. J Immunol 2009; 183: 4169-75.

56. Kamanaka M, Huber S, Zenewicz LA, et al. Memory/ effector $(\mathrm{CD} 45 \mathrm{RB}(\mathrm{lo})) \mathrm{CD} 4 \mathrm{~T}$ cells are controlled directly by IL-10 and cause IL-22- dependent intestinal pathology. J Exp Med 2011; 208: 1027-40.
57. Brand S, Beigel F, Olszak T, et al. IL-22 is increased in active Crohn's disease and promotes proinflammatory gene expression and intestinal epithelial cell migration. Am J Physiol Gastrointest Liver Physiol 2006; 290: 827-38.

58. Vonarbourg C, Mortha A, Bui VL et al. Regulated expression of nuclear receptor RORgammat confers distinct functional fates to NK cell receptor-expressing RORgammat(+) innate lymphocytes. Immunity 2010; 33: 736-51.

59. Lim C, Savan R. The role of the IL-22/IL-22R1 axis in cancer. Cytokine Growth Factor Rev 2014; 25: 257-71.

60. Savan R, McFarland AP, Reynolds DA et al. A novel role for IL-22R1 as a driver of inflammation. Blood 2011; 117: 575-84.

61. Park $\mathrm{O}$, Wang $\mathrm{H}$, Weng $\mathrm{H}$ et al. In vivo consequences of liver-specific interleukin-22 expression in mice: implications for human liver disease progression. Hepatology 2011; 54: 252-61.

62. Riccardi C, Santoni A, Barlozzari T, Puccetti P, Herberman RB. In vivo natural reactivity of mice against tumour cells. Int J Cancer 1980; 25: 475-486.

63. Wiltrout RH, Herberman RB, Zhang SR et al. Role of organ-associated NK cells in decreased formation of experimental metastases in lung and liver. J Immunol 1985; 134: 4267-4275.

64. Gorelik E, Herberman RB. Radioisotope assay for evaluation of in vivo natural cell-mediated resistance of mice to local transplantation of tumour cells. Int J Cancer 1981; 27: 709-720.

65. Gorelik E, Wiltrout RH, Okumura K, Habu S, Herberman RB. Role of NK cells in the control of metastatic spread and growth of tumour cells in mice. Int J Cancer 1982; 30: 107-112.

66. Jovanovic I, Radosavljevic G, Milovanovic M et al. Suppressed Innate Immune Response against Mammary Carcinoma in BALB/C Mice. Ser J Exp Clin Res 2012; 13: 55-61.

67. Standish LJ, Sweet ES, Novack J et al. Breast cancer and the immune system. J Soc Integr Oncol 2008; 6: 158-168.

68. Strayer DR, Carter WA, Mayberry SD et al. Low natural cytotoxicity of peripheral blood mononuclear cells in individuals with high familial incidences of cancer. Cancer Res 1984; 44: 370-374.

69. Hacene K, Desplaces A, Brunet M, Lidereau R, Bourguignat $\mathrm{A}$, Oglobine J. Competitive prognostic value of clinicopathologic and bioimmunologic factors in primary breast cancer. Cancer 1986; 57: 245-250.

70. Mohanty I, Nayak M, Nanda BK. Cell mediated immune status in carcinoma breast. Indian J Pathol Microbiol 1991; 34: 1-6.

71. Kauschke E, Komiyama K, Moro I, Eue I, König S, Cooper EL. Evidence for perforin-like activity associated with earthworm leukocytes. Zoology (Jena) 2001; 104: 13-24. 